\title{
Miasto jako kreator postępu - na przykładzie osiedla Nowe Żerniki we Wrocławiu (Osiedle Europejskiej Stolicy Kultury 2016)
} City as a creator of progress - on the example of the New Żerniki housing estate in Wrocław (Housing Estate of European Capital of Culture 2016)

\section{Streszczenie}

Miasta prowadzą politykę kreowania warunków zmierzających do zwiększania szans na dalszy rozwój. Niniejsze opracowanie jest analizą podejmowanych inicjatyw i roli miast w różnych formach organizacyjnych, a szczególnie w klastrach grupujących także uczelnie oraz firmy $i$ instytucje zaangażowane w zwiększanie dynamiki wzrostu, przy jednoczesnym zrównoważeniu działań i zachowaniu dbałości o środowisko naturalne. Działania te biorą także pod uwagę uwarunkowania społeczne i ekonomiczne, tak ważne w dłuższej perspektywie rozwoju.

Słowa kluczowe: miasto, kreatywność, klaster, zrównoważenie, osiedla wzorcowe

\section{Abstract}

Cities operate policies in creating conditions that lead to increase opportunities for further development. Analysis of the initiatives taken and the role of cities in various organizational forms, in particular clusters that group also universities, companies and institutions involved in process of increasing growth dynamics while balancing the actions and respect for the environment. These actions also have regard to social and economic conditions so important in the long term.

Keywords: city, creativity, cluster, sustainability, model settlements 
Miasta nie sq problemem - sq rozwiqzaniem. Cities are not the problem - they are the solution. Jaime Lerner, architekt, były burmistrz miasta Kurytyba, Brazylia

\section{WSTĘP}

Wiele miast zaangażowanych w rozwój i poszukiwanie tożsamości angażuje się także w przedsięwzięcia mające promować zarówno same miasta, jak i firmy wdrażające najnowsze technologie. Promocja wymusza angażowanie się także $w$ innowacyjne inwestycje (np. osiedla wzorcowe), traktując je jako poligon doświadczalny, a zarazem wzorzec do naśladowania oraz sposób na ukazanie potencjału miast.

Wrocław wielokrotnie podejmował próby organizacji spektakularnych wydarzeń. W związku z działaniami planowanymi na rok 2016, związanymi z Europejską Stolicą Kultury, władze miasta podjęły decyzję o budowie osiedla modelowego Nowe Żerniki, stwarzając tym samym okazję do bardziej kompleksowego i zrównoważonego spojrzenia na problem budowy osiedli mieszkaniowych.

Analiza podejścia do tworzenia zaplecza innowacyjnego - klastrów, a także wzorcowych osiedli mieszkaniowych - stwarza możliwość zrozumienia roli miast jako inicjatora czy kreatora postępu wymuszającego rozwój społeczny, ekonomiczny i przestrzenny.

\section{KLASTRY JAKO ZAPLECZE INTELEKTUALNO-STRUKTURALNE MIAST}

\subsection{GLASGOW - MIASTO DUŻYCH INWESTYCJI}

Future City Glasgow to duży i ambitny program z budżetem sięgającym 24 milionów funtów, służący zastosowaniu nowych technologii w celu poprawy jakości życia w zakresie racjonalności, bezpieczeństwa i zrównoważenia. Glasgow było jednym z 29 brytyjskich miast biorących udział w programie, a „(...) zwycięski projekt pokazał jak można połączyć wiedzę i umiejętności sektora publicznego, prywatnego i akademickiego z zastosowaniem najnowszych zdobyczy technologicznych w celu poprawy jakości codziennego życia w mieście, jednocześnie odnosząc się do tak ważnych kwestii, jak bezpieczeństwo publiczne, transport, ochrona zdrowia i zrównoważone źródła energii"1.

Aby zagrać o pełną stawkę, władze zainwestowały znaczne środki w infrastrukturę komunalną miasta o potencjale największym po stołecznym Londynie. Zainicjowały szereg wydarzeń i związanych z nimi inwestycji, m.in. organizację Igrzysk Brytyjskiej Wspólnoty Narodów z takimi inwestycjami towarzyszącymi, jak sieć cieplna, transportowa, system utylizacji odpadów; Centrum Technologii i Innowacji; plan zapobiegania powodziom czy projekt usprawnienia transportu, a także budowę szeregu nowych lub modernizacja historycznych obiektów. 


\subsection{KTH - UCZELNIA PRAWIE JAK KONCERN PRZEMYSŁOWY}

Szwedzki Królewski Instytut Technologiczny w Sztokholmie (KTH, Kungliga Tekniska Högskolan) jest uczelnią specjalizującą się w inżynierii i technologii. W kategorii dziedzin naukowych zajmuje on najwyższe miejsce w północnej Europie kontynentalnej (Szwecja, Skandynawia, Bałtyk, Polska i Północne Niemcy), z wyjątkiem Politechniki Technicznej w Monachium. Podstawą utworzenia KTH było Mechanica Laboratorium, założone w Sztokholmie w 1697 r. Zostało ono przekształcone w Szkołę Mechaniczną, a następnie, w 1827 r., w Instytut Technologiczny - pierwszy instytut techniczny w Szwecji (politechnikę) będący wzorcem dla paryskiej École Polytechnique. Obecnie instytucje i wydziały KTH są rozlokowane w kilku kampusach w okręgu Sztokholmskim, z siedzibami w Flemingsberg, Haninge, Kista, Södertälje i Östermalm, prowadząc różnorodną działalność. Dzisiaj KTH posiada wiele powiązań naukowo-biznesowych, co czyni z uczelni liczący się „koncern naukowo-badawczy”.

\subsection{BIZNESOWY WSCHODNI REGION SZWECJI - WSPÓŁDZIAŁANIA MAŁYCH MIAST W REGIONIE}

Biznesowy Region Wschodniej Szwecji oparty jest na współpracy wielu różnych partnerów rozlokowanych w Regionie Wschodnim. Obejmuje on głównie małe miasta, a jego dewizą jest: „Istniejemy dla przedsiębiorców i pilnujemy rozwoju we właściwym kierunku niezależnie od tego, czy chodzi o rozwój biznesu, finansowanie, innowacje, czy cokolwiek innego, co wzmocni rozwój naszego regionu"2 (il. 1). Klaster Szwecja Wschodnia, obejmujący miasta Linköping i Norrköping jako motory działań, zajmuje się rozległymi dziedzinami wiedzy i innowacji z udziałem wielu międzynarodowych firm, prowadząc badania naukowe i różnorodne programy w Linköping University. Udziałowcami w BRWS są miasta Linköping i Norrköping, Uniwersytet Linköping, Rada Regionalna Wschodniej Szwecji, BillerudKorsnäs Skärblacka AB, Danske Bank, Fastighets AB LE Lundberg, Henry Ståhl Fastigheter AB, Holmen Paper AB, Länsförsäkringar Östgöta, Norrköpings Tidningars Media AB, Saab AB, Swedbank $A B$, Toyota Material Handling Europe AB. Dzięki prowadzonym projektom oraz stałej współpracy z Uniwersytetem w Linköping, miastem Linköping i przedstawicielami biznesu Park Naukowy tworzy dominujący klaster gromadzący ok. 140 firm, skierowany na innowacje. W ten proces zaangażowane są organizacje i przedsiębiorstwa: Norrköping Municipality, Klövern, Europejski Fundusz Rozwoju Regionalnego, Acreo Swedish ICT, Norrköping utvecklingsstiftelse (Norrköping Development Foundation), Vinnova, Region Szwecji Wschodniej (Regionförbundet Östsam), Business Szwecja, Szwedzkiej Agencji ds. Wzrostu i Rozwoju Regionalnego.

Jak widać, Region Wschodni jest przykładem bardzo udanej współpracy małych miast tworzących duży potencjał zdolny konkurować ze znacznie większymi zespołami. 


\subsection{WROC ŁAWSKIE DZIAŁANIA - KLASTRY JAKO KOŁA ZAMACHOWE ROZWOJU}

Wrocław od wielu lat prężnie buduje wizerunek miasta kreatywnego. Angażuje swój potencjał w różnorodne przedsięwzięcia, próbując wypromować miasto i wzbudzić zainteresowanie za pomocą wydarzeń o skali europejskiej, a w konsekwencji pozyskać potencjalnych inwestorów.

Wiele lat temu miasto było jednym z pomysłodawców powołania Wrocławskiego Centrum Badań EIT, które parę lat później okazało się „(...) największym eksperymentem instytucjonalnym w dziedzinie badań naukowych i innowacji w Polsce. Jedyną i największą, zrodzoną z myślenia o rozwoju miasta, a przy tym na wskroś badawczo-innowacyjną spółką prawa handlowego" ${ }^{\prime 3}$. Na drodze do zawiązania spółki liderem był prezydent miasta Rafał Dutkiewicz. Dzisiaj EIT+ posiada najbardziej kompleksową infrastrukturę badawczą w Europie środkowo-wschodniej, wyposażoną w najnowszy sprzęt laboratoryjny i pozwalającą realizować cenne dla przemysłu aplikacyjne projekty badawcze oraz badania podstawowe uwzględniające światowe trendy rozwojowe. EIT+ ma powiązania z najlepszymi światowymi ośrodkami współpracującymi z przemysłem, takimi jak: Berkeley, Stanford, Princeton, Fraunhofer Institute, Gent University.

Raport Potencjał i potrzeby badawczo-rozwojowe przedsiębiorstw aglomeracji wrocławskiej przygotowany przez PWC, Antal i Agencję Rozwoju Aglomeracji Wrocławskiej SA, pozytywnie ocenia działania miasta w oparciu o analizę dziewięciu inwestycji mających znaczenie dla postrzegania Wrocławia. Są to: Obwodnica Autostradowa Wrocławia, rozbudowa systemu dróg ekspresowych, Stadion Miejski, nowy terminal lotniska, rozbudowa sieci tramwajowej i modernizacja floty tramwajów i autobusów, Narodowe Forum Muzyki, Aquapark i Afrykarium, kompleksowy program modernizacji szkół w mieście i wreszcie modernizacja Wrocławskiego Węzła Wodnego, zwiększająca bezpieczeństwo przeciwpowodziowe. Autorzy dostrzegają także, iż: „Wrocław coraz częściej doceniany jest jako ważny i interesujący ośrodek życia ekonomicznego i społeczno-kulturalnego, co znajduje wyraz w organizacji pre-

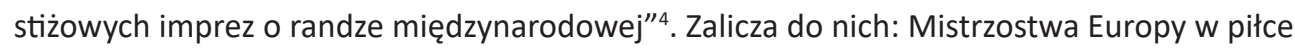
nożnej UEFA EURO 2012, Europejską Stolicę Kultury 2016, Światową Stolicę Książki UNESCO 2016 i Igrzyska Sportów Nieolimpijskich World Games 2017. Ta strategia pozwoliła także na zajęcie 1. miejsca w rankingu „Miasta Przyszłości” w kategorii „przyciąganie inwestycji” i 3. w kategorii „przyjazne biznesowi”, przyznane przez „fDi Magazine”. W regionie działa wiele klastrów technologicznych, w tym Wrocławskie Centrum Transferu Technologii WCTT, Dolnośląski Klaster Ekoenergetyczny EEI - Energia, Ekologia, Innowacje oraz Dolnośląski Inkubator Technologiczny wraz z Centrum Innowacji utworzony przez Dolnośląską Agencję Współpracy Gospodarczej.

Wśród najważniejszych klastrów brakuje jednak klasycznych klastrów cleantech z różnorodnym udziałem firm i instytucji regionalnych, co może świadczyć albo o słabości tych instytucji zajmujących się wdrażaniem innowacyjnych technologii (w poszczególnych 
klastrach), albo o braku wsparcia finansowego ze strony gmin czy instytucji o charakterze regionalnym bądź narodowym.

Brak zainteresowania ze strony klastrów w trakcie konstruowania osiedla Nowe Żerniki jest także symptomatyczny.

\section{PRZYKŁADY REALIZACJI KREATYWNEGO PODEJŚCIA MIAST}

\subsection{POCZĄTKI}

Jednym z pierwszych przypadków kreatywnego podejścia do budowy zespołów mieszkaniowych jest opisywane przez Izabelę Mironowicz osiedle wybudowane przez Fuggera w pierwszej połowie XVI wieku, którego „(...) celem było zapewnienie bezpieczeństwa i dachu nad głową bez związku z prawem własności"5 i w którym każdy miała prawo przebywać do końca życia bez prawa do dziedziczenia wynajmu.

\subsection{KURYTYBA - ZINTEGROWANA SIEĆ TRANSPORTOWA}

Rozpoczęcie budowy smart city nie byłoby zapewne możliwe bez wcześniejszych działań miasta, rozpoczętych w 1979 r., kiedy to powołany na stanowisko burmistrza miasta Curitiba młody architekt Jaime Lerner zainicjował stworzenie Zintegrowanej Sieci Transportowej (Rede Integrada de Transporte) (il. 2), czyli układu szybkich linii autobusowych mających usprawnić system transportowy. Po rozbudowie przedsięwzięcie to zyskało dużą popularność nie tylko w Brazylii. W 1993 r. sieć przewoziła 1,5 miliona pasażerów dziennie, a dzisiaj prawie 2,3 miliona.

Sukces tego pomysłu zaowocował w 2013 r. wprowadzeniem kolejnych rewolucyjnych rozwiązań komunikacyjnych i technologicznych wspartych na IT, dając szansę na ponowne przemyślenia rozwoju miasta. Sztokholmski Królewski Instytut Technologiczny (KTH), miasto Kurytyba oraz liczne instytucje, w tym lokalne uczelnie wyższe i Federacja Przemysłowa stanu Paraná, podpisały protokół porozumienia w celu opracowania projektów w zakresie mobilności, planowania przestrzennego i środowiska. Zawiązane na podstawie porozumienia konsorcjum, w skład którego weszły KTH, VOLVO, SAAB Combitech, UTFPR (Uniwersytet Techniczny w Paraná), URBS i Instituto Pépquisa e Planejamento Urbano de Curitiba, ma na celu zbadanie możliwości zastosowania nowych technologii na rzecz poprawy mobilności i efektywności energetycznej w Kurytybie, a także zapewnienie zrównoważonych rozwiązań technologicznych zmierzających do poprawy infrastruktury o kluczowym znaczeniu w mieście. Inicjatywa dotyczy problemów związanych z efektywnością energetyczną oraz emisją gazów cieplarnianych w transporcie publicznym i opiera się na stworzeniu nowych korytarzy transportu publicznego w Kurytybie, a także na przedstawieniu nowych koncepcji zrównoważonego miasta. Prace badawcze prowadzone są przez KTH i UTFPR w celu przetestowania 
i wyboru koncepcji odpowiadających Kurytybie, zaprojektowania konfiguracji systemów infrastrukturalnych, monitorowania przebiegu operacji oraz zapewnienia równowagi między produkcją energii a zanieczyszczeniami. Ambicją twórców tego przedsięwzięcia jest stworzenie referencji o międzynarodowej skali dla takich przedsięwzięć, a także wzmocnienie wzajemnych relacji szwedzko-brazylijskich nie tylko w Kurytybie, ale także w całej Brazylii. Projekt przewidziano na lata 2014-2017.

\subsection{LONDYN - GREENWICH MILLENIUM VILLAGE}

„Greenwich Millennium Village odegrało w Wielkiej Brytanii pionierską rolę - powstało jako modelowa realizacja służąca ukazaniu możliwości kształtowania zespołów mieszkaniowych zgodnie z ideami rozwoju zrównoważonego" ${ }^{\prime 6}$. Obszar o wielkości 120 ha jest zlokalizowany na terenach poprzemysłowych, co wzmacnia aspekt zrównoważenia w ujęciu szerszym - miejskiej struktury. Chcąc aktywować przestrzeń poprzemysłową, miasto przedłużyło linię metra (Jubilee line) oraz przystąpiło do budowy hali widowiskowej Millenium Dome, co pozwoliło na skuteczne „odzyskanie” całego poprzemysłowego terenu, czyniąc go bardziej atrakcyjnym. English Partnerships, angielska agencja do spraw rehabilitacji, w 1997 r. nabyła południową część terenów dawnej gazowni i ogłosiła konkurs na realizację modelowego zespołu mieszkaniowego. Celem tej realizacji miała być popularyzacja idei kształtowania zabudowy mieszkaniowej, zwłaszcza o dużej skali, w zgodzie z zasadami rozwoju zrównoważonego.

Wśród podstawowych warunków, jakie spełniać miała nowa zabudowa, znalazły się następujące: zmniejszenie o 80\% zużycia energii w nowej zabudowie (w porównaniu z typowym), zmniejszenie o 30\% zużycia wody oraz ograniczenie o 50\% wielkości odpadów powstających w trakcie budowy.

Autorem projektu zespołu Greenwich Millennium Village był Ralph Erskine. Całość zaplanowana jest na 1377 jednostek mieszkaniowych dla około 7,5 tysiąca mieszkańców, przy czym około $20 \%$ nowej zabudowy stanowić powinno budownictwo socjalne. Zespół Millennium Village charakteryzuje się znacznym zróżnicowaniem zastosowanych typów zabudowy mieszkaniowej. Od strony Tamizy zaprojektowano najwyższe, osiągające wysokość 12 kondygnacji, budynki wielorodzinne, które chronić mają niższą, znajdującą się wewnątrz zespołu, zabudowę przed zimnymi wschodnimi wiatrami. Zastosowanie dużych fragmentów wody (il. 3) pozwala odtworzyć pierwotny krajobraz i układ roślinny nadrzecznych mokradeł, a także umożliwia użycie roślinności jako filtra zanieczyszczeń wodnych.

\subsection{MALMÖ - BO01}

Bo01 położone na terenie Zachodniego Portu (Vastra Hamnen) w Malmö było zaplanowane i wybudowane w związku organizacją wystawy EXPO 2001 poświęconej problemom mieszkalnictwa. Planowana z tej okazji realizacja „Miasta Przyszłości” (City of Tomorrow) 
jest przykładem różnorodności rozwiązań architektonicznych. „W zagospodarowaniu terenu ważne było stworzenie kameralnych wnętrz dla różnego rodzaju zabudowy mieszkaniowej. "Rozmaitość» była głównym hasłem wiodącym zarówno przy projektowaniu planu zagospodarowania, jak i struktury mieszkaniowej i samej formy architektonicznej"7. Działania dotyczące odnawialnych źródeł energii i zwiększonej bioróżnorodności w połączeniu z innymi inicjatywami stworzyły spójną koncepcję zrównoważonego rozwoju dla całego obszaru regeneracji. Wszystkie domy zostały zbudowane według standardów określonych w Programie Jakości ustalonym wspólnie przez organizatorów Bo01, deweloperów i miasto Malmö. Program określał wytyczne dotyczące jakości architektonicznych, wyboru materiałów, zużycia energii, kwestii ekologicznych i infrastruktury technicznej.

Jednym z ważniejszych wyzwań „Miasta Przyszłości” był problem energii i wód deszczowych. Aby ograniczyć zużycie energii i ciepła, zawiązano umowy z deweloperami poszczególnych obiektów. System Bo01 wytwarza samodzielnie ciepło, chłód i energię elektryczną w oparciu o pompy ciepła i złoża geotermalne (il. 4). Wewnętrzny system jest podłączony do sieci, ale w bilansie rocznym dzielnica wytwarza potrzebną ilość energii i jest samowystarczalna. System odprowadzania wody deszczowej, prowadzonej głównie wzdłuż ulic (il. 5), został zaprojektowany tak, aby był estetyczny: z wodospadami, stawami i różnymi elementami do buforowania i oczyszczania wody. Zielone dachy pomagają natomiast zmniejszyć ilość wody deszczowej.

\subsection{WROC ŁAW - WUWA 1929}

Początek XX wieku to okres zmian społeczno-ekonomicznych i światopoglądowych, będących powodem powołania platformy wymiany myśli i idei pod nazwą Werkbund. Skupiała ona postępowych producentów, architektów i projektantów pracujących dla przemysłu. Był to zapewne pierwowzór dzisiejszych klastrów. Rozwiązywanie problemu mieszkaniowego po I wojnie światowej stało się możliwe dzięki wzrostowi gospodarczemu i stabilnej sytuacji ekonomicznej, wzmocnionej podatkiem od domów czynszowych. Znaczny wpływ miało także dojście do władzy środowisk socjaldemokratycznych, które stały za realizacją planów budowy większych osiedli mieszkaniowych, głównie dla mas pracujących.

Możliwością wzrostu liczby mieszkań miały się zająć powołane w tym czasie towarzystwa i spółdzielnie, w tym np. Państwowe Towarzystwo Badawcze ds. Ekonomiki Budownictwa i Mieszkalnictwa, którego celem było badanie i wdrażanie racjonalnej zabudowy oraz wspieranie realizacji wzorcowych przykładów zabudowy mieszkaniowej.

W swoich krajowych sekcjach Werkbund zorganizował wystawy mieszkaniowe, które były ściśle powiązane z realizacją wzorcowych osiedli. Wystawy w Stuttgarcie, Brnie, Wrocławiu (Breslau), Zurychu i Pradze cechowało ściśle regionalne podejście. Na WuWę we Wrocławiu zaproszono tylko lokalnych architektów. 
Zorganizowana w 1929 r. we Wrocławiu WuWA była zainicjowana przez oddział śląski Werkbundu, a zrealizowana została przez Towarzystwo Osiedlowe Wrocław SA oraz miasto Wrocław. Podstawowym „(...) celem budowy osiedla było przedstawienie nowych typów tanich małych i średnich mieszkań oraz nowej formy domów, nowych technologii i materiałów budowlanych"8. Innowacyjne technologie miały być przetestowane w trudnym wrocławskim klimacie, a nowe formy miały dotyczyć także zróżnicowanych potrzeb rodzinnych.

\subsection{WROCŁAW - NOWE ŻERNIKI 2016}

Dolnośląska Okręgowa Izba Architektów, we współpracy z wrocławskim Oddziałem SARP, jako pomysłodawca projektu, przy współudziale miasta i pod patronatem prezydenta Wrocławia, rozpoczęła w 2012 r. działania warsztatowe, w których wzięło udział 44 zaproszonych wrocławskich architektów wraz z zespołami, a także konsultanci, specjaliści z urzędu miasta oraz deweloperzy-inwestorzy. W pierwszej fazie prace warsztatowe nad opracowaniem założeń do Miejscowego Planu Zagospodarowania Przestrzennego, w obecności przedstawicieli lokalnej społeczności (elementy konsultacji), były także innowacyjnym podejściem do zaprojektowania modelowego zespołu mieszkaniowego. Koordynatorem projektu był Architekt Miasta. Projektowane osiedle odpowiadać miało potrzebom przyszłych mieszkańców, ułatwiać budowanie więzi społecznych, sprostać normom budownictwa ekologicznego, a także stać się architektoniczną wizytówką Europejskiej Stolicy Kultury w 2016 roku.

Założenia projektowe zapisano w dwóch grupach tematycznych:

A. założenia ogólne, urbanistyczne

- przestrzenie publiczne służące mieszkańcom - integracja, rekreacja

- usługi podstawowe - opieka nad dzieckiem, edukacja, handel, gastronomia

- bezpieczeństwo

- przeciwdziałanie wykluczeniu społecznemu

- ekologia, minimalizacja wydatków eksploatacyjnych

- optymalizacja komunikacji - współdziałanie z systemem komunikacji miejskiej

- nowe formy organizacji budownictwa

- udział społeczeństwa

B. założenia funkcjonalne, architektoniczne

- przestrzenie prywatne, półprywatne, półpubliczne, publiczne

- optymalizacja struktury mieszkań

- lokalne tradycje materiałowe i wykonawcze

- miejsce pracy: małe powierzchnie adresowane dla działalności zawodowej

- technologie zintegrowanego projektowania

- różne formy domów mieszkalnych: duże budynki mieszkalne ,małe domy wielorodzinne, wille miejskie: próba stworzenia domu modelowego 
„Nowe Żerniki to modelowe osiedle, które ma stać się alternatywą do «produkcji taśmowej» mieszkań - mocno ujednoliconej i nie zawsze jakościowo zadowalającej oferty generowanej przez rynek" ${ }^{\prime \prime}$. Miasto postanowiło przejąć inicjatywę i koordynować działania planistyczne oraz projektowe, a także gwarantować realizację kompleksowego zespołu mieszkaniowego. Dzięki współudziałowi Gminy Wrocław, architektów i inwestorów projekt zakładał w ramach osiedla budowę całej niezbędnej infrastruktury - począwszy od infrastruktury podziemnej, przez sieć dróg i chodników, oświetlenie terenu, aranżację zieleni, aż po kompletne wyposażenie przestrzeni publicznych oraz budowę obiektów niezbędnych dla sprawnego funkcjonowania już na etapie realizacji. Inwestorzy prywatni stali się odpowiedzialni za realizację zabudowy mieszkaniowej i zagospodarowania terenów przestrzeni prywatnej, półprywatnej oraz półpublicznej.

Lokalizację wybrano kierując się przesłankami zrównoważonego rozwoju, czyli bliskiego i sprawnego układu komunikacji publicznej. Przedmiotowa działka jest usytuowana w zachodniej części miasta, w pobliżu Stadionu Miejskiego oraz w pobliżu węzła przesiadkowego (kolej, tramwaj, autobus i P+R). Obszar Nowych Żernik w pierwszym etapie ma wielkość ok. 10 ha. Drugi etap, po zmianie zapisów w Studium Wrocławia, obejmie łącznie ok. 40 ha (il. 6), a kolejne zaplanowane są na 100 ha z możliwością powiększenia do ok. 300 ha, oczywiście z uwzględnieniem terenów przeznaczonych pod aktywność gospodarczą. Ten układ zróżnicowania funkcjonalnego jest ważnym atrybutem zrównoważenia jako deklaracji ideowej i zapewnia miejsca pracy blisko miejsc zamieszkania, a tym samym zmniejszenie obciążenia układu komunikacji.

Nowe Żerniki pomyślane zostały jako jednostka wyposażona w elementy podnoszące komfort życia, takie jak bazarek czy Centrum Aktywności Lokalnej i Kultury, ale przede wszystkim jako kompleksowo wyposażone osiedle mieszkaniowe, na którym znajdzie się szkoła, dom seniora połączony z przedszkolem oraz przestrzenie do wykorzystania zgodnie z potrzebami mieszkańców. Zaplanowano różnicowanie struktury zabudowy - od dużych budynków wielorodzinnych (kwartały), poprzez kameralne jednostki złożone z kilku mieszkań, a także domy jednorodzinne. Ma to umożliwić stworzenie heterogenicznej struktury społecznej oraz spowodować zaangażowanie różnorodnych inwestorów - deweloperów, małych spółdzielni, kooperatyw czy inwestorów indywidualnych.

Istotnym i nowym elementem struktury mieszkaniowej są właśnie wyżej wspomniane kooperatywy, które dużo łatwiej wdrażają innowacyjne rozwiązania, bo - jak podaje Kristien Ring, autorka Selfmade City: „W Berlinie jest godny zauważenia fakt, iż jakość ekologiczna jest także związana z jakością architektury, a samodzielnie zrealizowane budynki (selfmade) stosowały nowe technologie i nowe standardy dużo wcześniej aniżeli zostały wprowadzone stosowne wymagania"10. Tą drogą zapewne podąża miasto Wrocław, zachęcając i testując rozwiązanie oparte o wyniki berlińskich doświadczeń.

Kwestia ekologii miała dotyczyć czterech ważnych zagadnień: wody deszczowej (il. 7), oświetlenia ulicznego, śmieci oraz komunikacji. Miasto zorganizowało zwiedzanie osiedla modelowego Bo01 w Malmö, a później toczyło rozmowy z kilkoma firmami ze Szwecji, zaś 
przedstawiciel Cleantech Östergötland, Samar Nath, Business Developer, przedstawił przedstawicielom władz municypalnych założenia ekologii w ujęciu systemowym. Wrocław jednak z wielu względów nie był w stanie ani nawiązać bliższej współpracy z lokalnymi przedstawicielami, ani skorzystać z wiedzy bardziej zaawansowanych zagranicznych firm. Rozważane były także możliwości zaangażowania jednego z dużych banków w proces finansowania oraz wprowadzenie linii autobusów elektrycznych (rozmowy z firmą VOLVO), jednak bez powodzenia. Regulacje prawne nie pozwalają również na wprowadzenie idei mieszkań na wynajem - czyli mieszkań łatwo dostępnych.

\section{PODSUMOWANIE}

Miasta starają się planować rozwój, koncentrują działania, budują infrastrukturę i wspierają rozwój mający ułatwić życie przyszłym użytkownikom - zarówno indywidualnym, jak i zbiorowym.

Dysponując funduszami na rozwój, w celu osiągnięcia sukcesu miasta powinny rozpocząć od inwestowania i wspierania lokalnych działań kreatywnych firm oraz instytucji. Miasta kreatywne to takie, które potrafią nakreślić śmiały scenariusz działań, przedsięwziąć wydarzenia ważne w skali ponadnarodowej, a następnie zainteresować ich realizacją zarówno firmy wykonawcze aspirujące do grona liderów wdrażających najnowsze osiągnięcia myśli technicznej, jak i instytucje naukowe oraz uczelnie mogące wspierać kreatywne działania wiedzą i doświadczeniem.

Greenwich Millenium Village w Londynie, osiedle Bo01 w Malmö czy Future City w Glasgow to przykłady właśnie takiego procesu budowania i wspierania kreatywnego rozwoju miasta. Biznesowy Wschodni Region Szwecji jest z kolei przykładem nie tylko kreatywnego myślenia, ale także pożytków płynących ze współpracy między gminami, uczelniami i instytutami badawczymi oraz firmami oferującymi najnowsze technologie, gdzie wspieranie własnych pomysłów prowadzi do wielokrotnego zwiększenia potencjału i możliwości stosunkowo niewielkiego regionu.

Wrocławskie Nowe Żerniki są natomiast kolejnym przykładem aspiracji Wrocławia jako stymulatora kreatywnego myślenia, a także miasta próbującego wskazywać nowe pola działania na razie na poziomie narodowym. 


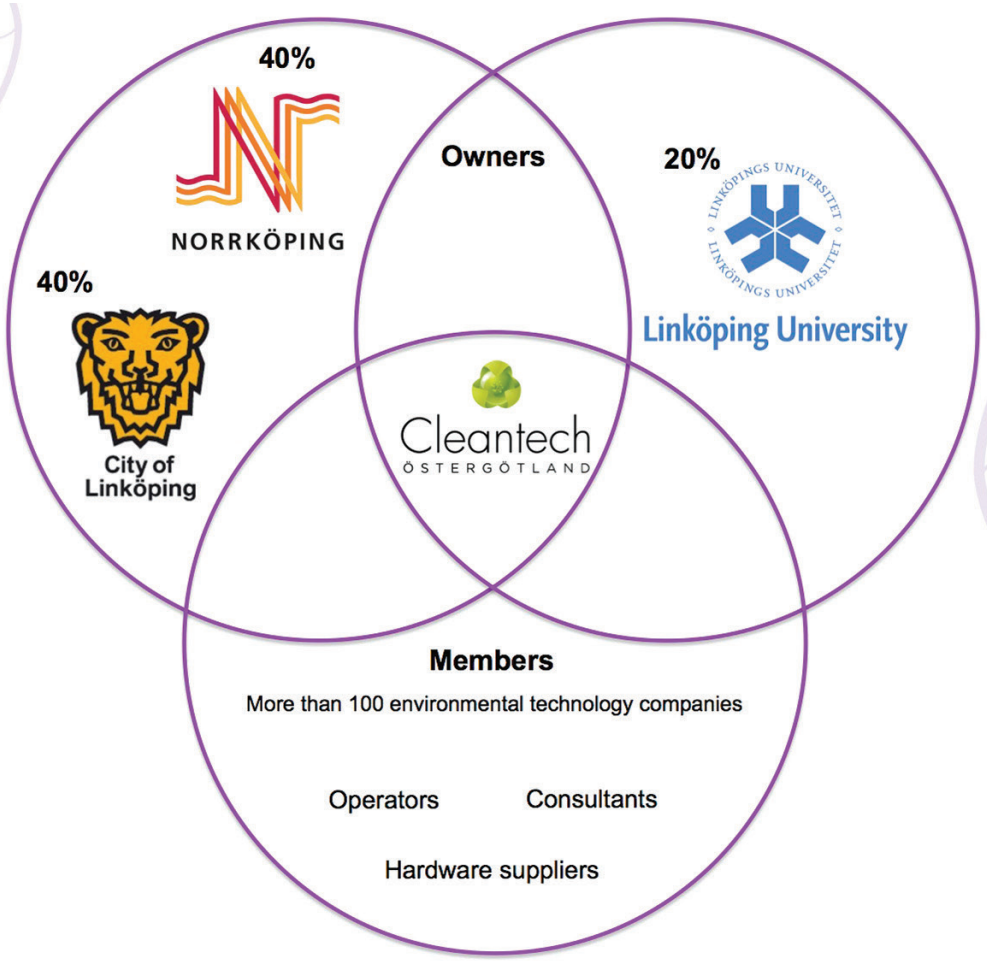

II. 1. Biznesowy Wschodni Region Szwecji - struktura udziału w klastrze III. 1. East Sweden Bussines Region - share structure in cluster, Samar Nath, Business Developer, Cleantech Östergötland 


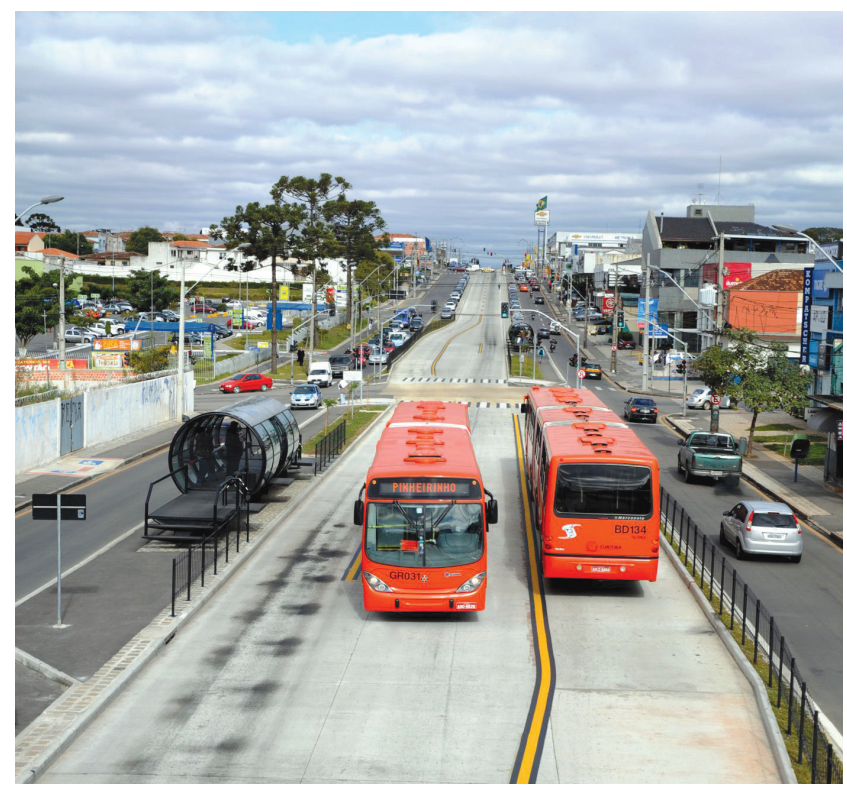

II. 2. Kurytyba - system lin autobusowych i przystanków

(źródło: http://www.c40.org/blog_posts/curitiba-a-leader-in-transport-innovation) III. 2. Curitiba - bus line and bus stops system

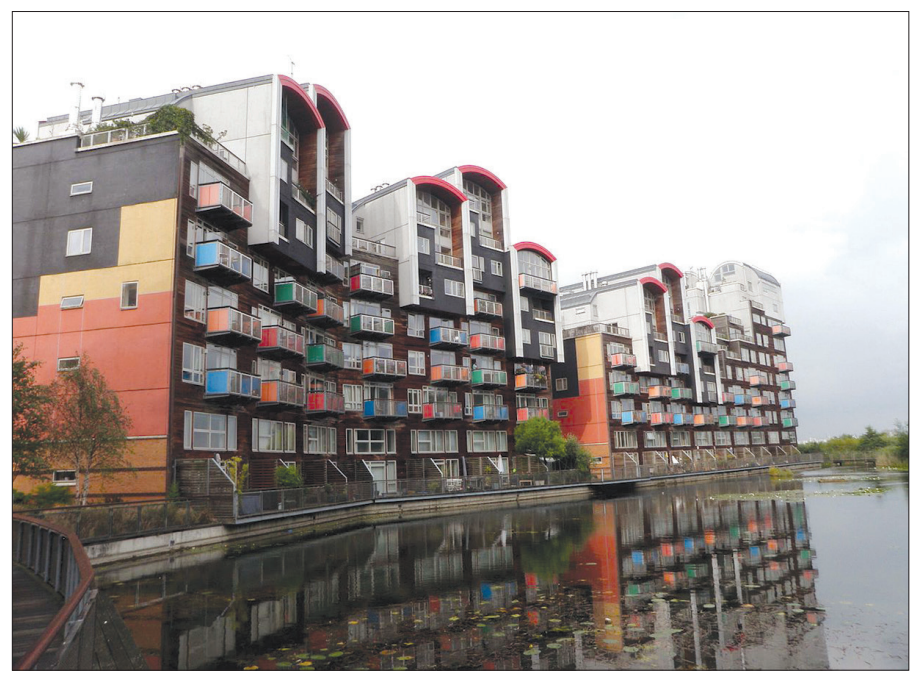

II. 3. Greenwich Millenium Village - zarządzanie wodą deszczową (źródło: http://www.sto.pl/pl/o-firmie/referencje/references-detailview_13969.html) III. 3. Greenwich Millenium Village - water management 


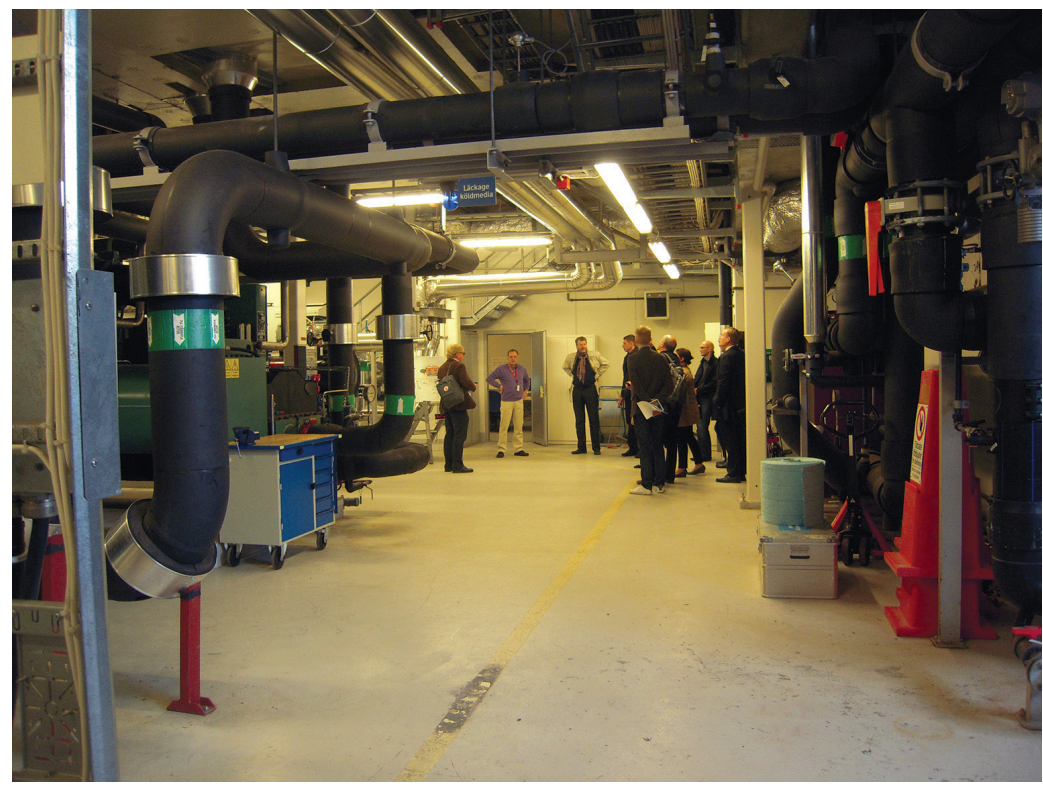

II. 4. Bo01 - Urządzenia pomp ciepła (fot. M. Hawrylak) III. 4. Bo01 - Heating pump equipment

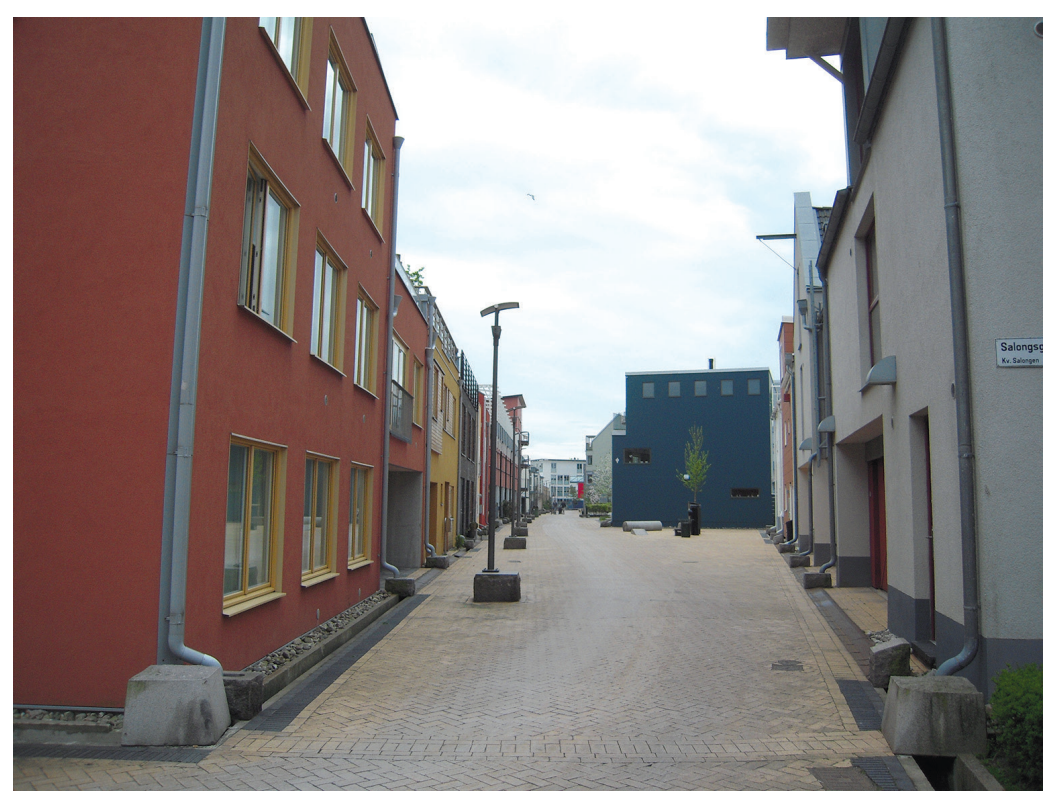

II. 5. Bo01 - Kanały wód deszczowych wzdłuż dróg (fot. M. Hawrylak) III. 5. Bo01 - Rainwater canals along the roads 


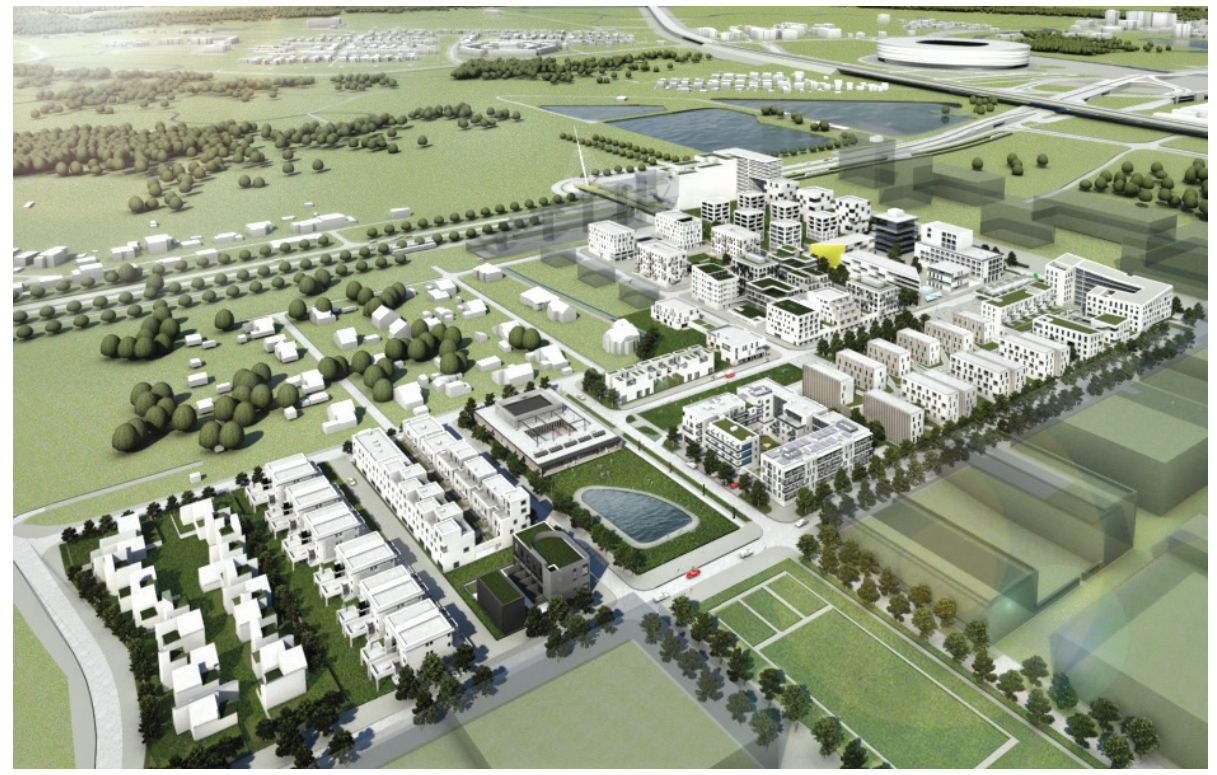

II. 6. Nowe Żerniki - aksonometria osiedla (źródło: http://nowezerniki.pl/realizacje) III. 6. Nowe Żerniki - axonometry of settlement

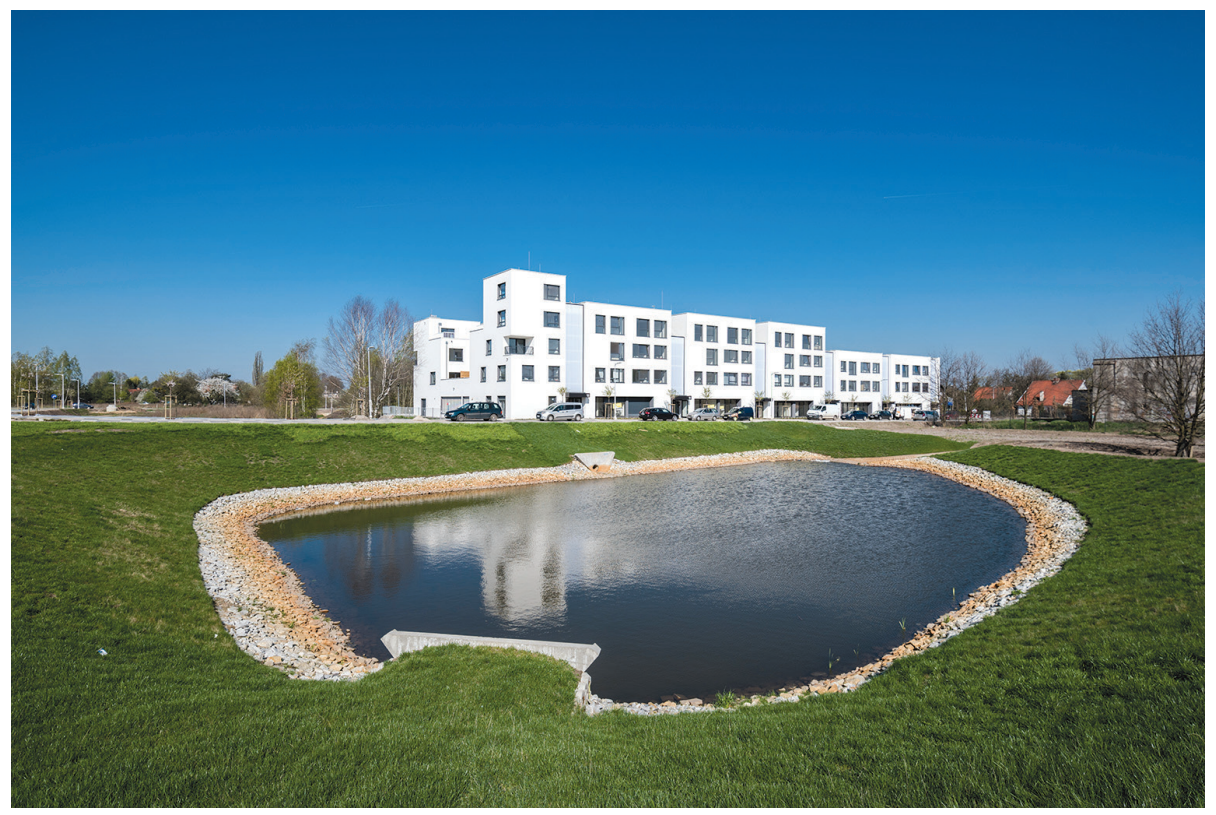

II. 7. Nowe Żerniki - zbiornik wód deszczowych (fot. M. Lulko)

III. 7. Nowe Żerniki - Rainwater tank 


\section{PRZYPISY}

1 Poszukiwanie modelu inteligentnego rozwoju. Przykład Gdańska i Glasgow, J. Bach-Głowińska (red.), Wolters Kluwer SA, 2015.

2 „We exist for entrepreneurs and to pilot you in the right direction whether it's about business development, financing, innovation or anything else that will strengthen our region's growth", http://www.eastsweden.com/business/about-us/organisations.

3 M. Litwin, Masa, Przyśpieszenie i talent, czyli krótki esej o poczq̨tkach ElT+, http://www. eitplus.pl/wp-content/uploads/2016/08/Esej-Maciej-Litwin.pdf

4 Potencjat i potrzeby badawczo rozwojowe przedsiębiorstw w aglomeracji wrocławskiej, https://www.pwc.pl/pl/pdf/potencjal-i-potrzeby-badawczo-rozwojowe-przedsiebiorstw-w-aglomeracji-wroclawskiej-raport.pdf

5 I. Mironowicz, Modele Transformacji miast, Oficyna Wydawnicza PWr, Wrocław 2016.

6 A. Klimek, Kształtowanie środowiska mieszkaniowego wedle zasad rozwoju zrównoważonego. Przykład Greenwich Millennium Village w Londynie, Czasopismo Techniczne, 3-A/2017, s. $115-124$.

7 E. Kusińska, Miasto przyszłości - zrównoważona dzielnica mieszkaniowa, Czasopismo Techniczne, 3-A/2017, s. 163-170.

8 Droga ku Nowoczesności. Osiedla Werkbundu 1927-1932, J. Urbanik (red.), Muzeum Architektury we Wrocławiu, Wrocław 2016.

9 http://nowezerniki.pl/idea

${ }^{10}$ K. Ring, Selfmade City, Jovis, Berlin 2013.

\section{BOBLIOGRAFIA}

\section{Wydawnictwa książkowe}

Mironowicz I., Modele Transformacji miast, Oficyna Wydawnicza PWr, Wrocław 2016.

Ring K., Selfmade City, Jovis, Berlin 2013.

\section{Prace zbiorowe}

Droga ku Nowoczesności. Osiedla Werkbundu 1927-1932, J. Urbanik (red.), Muzeum Architektury we Wrocławiu, Wrocław 2016.

Poszukiwanie modelu inteligentnego rozwoju. Przykład Gdańska i Glasgow, J. Bach-Głowińska (red.), Wolters Kluwer SA, 2015.

Sustainable Urban Design. The next step, M. Meijer, M. Dubbeling, A. Marcelis (red.), Blauwdruk 2010.

WuWA - Mieszkanie i miejsce pracy. Wrocławska wystawa Werkbundu, praca zbiorowa, Wrocławska Rewitalizacja Sp. z o.o., Wrocław 2014. 


\section{Artykuły}

Klimek A., Kształtowanie środowiska mieszkaniowego wedle zasad rozwoju zrównoważonego. Przykład Greenwich Millennium Village w Londynie, Czasopismo Techniczne, 3-A/2017, s. $115-124$.

Kusińska E., Miasto przyszłości - zrównoważona dzielnica mieszkaniowa, Czasopismo Techniczne, 3-A/2017, s. 163-170.

Strony internetowe (dostęp: 7.04.2017)

atelier GROENBLAUW, The social and economic importance of green and blue areas, http:// www.urbangreenbluegrids.com/social

Cleantech ostergotland, podstrona: The sustainable cycle in Linköping, http://cleantechostergotland.se/det-hallbara-kretsloppet-i-linkopin

How Denmark is world's most clean-tech country, http://economictimes.indiatimes.com/ et-cetera/how-denmark-is-worlds-most-clean-tech-country/articleshow/6820776.cms

Litwin M., Masa, Przyśpieszenie i talent, czyli krótki esej o poczq̨tkach ElT+, http://www. eitplus.pl/wp-content/uploads/2016/08/Esej-Maciej-Litwin.pdf

http://nowezerniki.pl/idea

Potencjał i potrzeby badawczo rozwojowe przedsiębiorstw w aglomeracji wrocławskiej, https://www.pwc.pl/pl/pdf/potencjal-i-potrzeby-badawczo-rozwojowe-przedsiebiorstw-w-aglomeracji-wroclawskiej-raport.pdf

Smart City Concepts in Curitiba. Innovation for sustainable mobility and energy efficiency, NEWSLETTER, April 2017, www.ecs.kth.se

Sustainable Energy actions in four cites, http://malmo.se/download/18.58f28d93121ca033 d5e800086/1491299833011/secure_webb2.pdf

How Denmark is world's most clean-tech country, http://economictimes.indiatimes.com/ et-cetera/how-denmark-is-worlds-most-clean-tech-country/articleshow/6820776.cms http://www.eastsweden.com/business/about-us/organisations

\section{Prezentacje}

CIRCULAR ECONOMY, Industrial Ecology at Work in Östergötland, Samar Nath, Business Developer, Cleantech Östergötland, prezentacja dla przedstawicieli miasta Wrocław (pdf). 